Saliman, Supardi, Raras Gistha Rosardi

\title{
PEMAHAMAN MAHASISWA PESERTA PENGAJARAN MIKRO TERHADAP KURIKULUM 2013 DI JURUSAN PENDIDIKAN IPS, FIS, UNY
}

\author{
Saliman \\ Supardi \\ Raras Gistha Rosardi
}

\section{Jurusan Pendidikan IPS, FIS UNY No. Hp 08122747937 email: salimanjaper@uny.ac.id}

\begin{abstract}
Abstrak
Penelitian ini bertujuan untuk untuk mengetahui sejauh mana tingkat pemahaman mahasiswa peserta pengajaran mikro terhadap kurikulum 2013 di jurusan Pendidikan IPS dan untuk mengetahui upaya yang dilakukan selama ini di jurusan Pendidikan IPS agar mahasiswa peserta pengajaran mikro mampu memahami kurikulum 2013. Metode penelitian yang digunakan adalah penelitian deskriptif kuantitatif. Instrumen penelitian yang digunakan adalah angket. Sampel yang diambil sebanyak 81 mahasiswa peserta pengajaran Microteaching. Teknik analisis data yang digunakan dalam penelitian ini adalah dengan data persentase dan diagram untuk menunjukkan tingkat pemahaman sampel terhadap kurikulum 2013. Hasil penelitian diperoleh data bahwa mahasiswa yang memiliki tingkat pemahaman sangat tinggi sebesar 43,68\%, tinggi sebesar 24,36\%, sedang sebesar 0\% dan rendah sebesar $0 \%$. Kategori pemahaman sangat tinggi diperoleh sebanyak 43,68\% mahasiswa, walaupun belum sampai 50\% akan tetapi persentase ini dapat dikatakan sudah baik. Berdasarkan data hasil penelitian tersebut dapat diketahui bahwa pemahaman mahasiswa jurusan Pendidikan IPS terhadap kurikulum 2013 sangat didukung oleh mata kuliah yang mendukung terhadap kebijakan pendidikan, perangkat pembelajaran di sekolah, dan strategi pembelajaran di kelas. Pemahaman kurikulum 2013 diperlukan agar mahasiswa jurusan Pendidikan IPS siap untuk terjun di lapangan dalam kegiatan PPL (Praktek Pengajaran Lapangan).
\end{abstract}

Kata kunci: pemahaman, mikro dan kurikulum 2013 


\begin{abstract}
This study aimed to determine the extent of understanding of students participating in micro teaching to the curriculum in 2013 with a major in social studies education and to know the efforts made so far in the Department of Education so that students participating IPS micro teaching is able to understand the curriculum, 2013. The method used is descriptive quantitative research. The research instrument used was a questionnaire. Samples taken as many as 81 students participating in the teaching of Microteaching. Data analysis techniques used in this study is the percentage data and diagrams to show the level of understanding of the sample to the curriculum in 2013. The results of the research data showed that students who have a very high level of understanding of 43.68\%, higher by 24.36\%, while the low of $0 \%$ and $0 \%$. Category very high understanding gained as much as $43.68 \%$ of the students, although not yet up to $50 \%$ but this percentage can be said is good because in 2014, teaching the students participating in the micro and PPL. Based on research data, it is known that the students' understanding of the curriculum Education Department IPS 2013 is supported by courses that support the educational policies, learning tool in schools, and learning strategies in the classroom. 2013 curriculum understanding necessary for students majoring in social studies education in the field ready to plunge in activity PPL (Teaching Practice Field). This is because the students sampled in this study is the first generation that is involved in the implementation of the curriculum in 2013.
\end{abstract}

Keywords: comprehension, micro and curriculum 2013

\title{
Pendahuluan
}

Pemerintah terus berupaya untuk memperbaiki kualitas pendidikan di Indonesia salah satunya dengan melakukan perbaikan kurikulum. Pada tahun 2013 ini, pemerintah mensosialisasikan kurikulum baru 2013. Kurikulum ini diharapkan menjadi lokomotif kemajuan pendidikan mulai tahun 2013 sampai seterusnya. Perubahan yang dilakukan pada kurikulum baru ini berdasarkan atas evaluasi atas kurikulum 
Saliman, Supardi, Raras Gistha Rosardi

sebelumnya. Beberapa yang menjadi fokus analisis adalah terlalu banyak aspek kognitif yang dibebankan kepada siswa sehingga menjadikan siswa kurang mendapat ruang cukup luas untuk mengembangkan kepribadian dan kecakapan selain akademik. Wakil Menteri Pendidikan dan Kebudayaan Bidang Pendidikan, Musliar Kasim, mengatakan bahwa perombakan kurikulum ini penting dilakukan. Ia berpendapat dengan perubahan kurikulum ini, anak-anak mempunyai waktu untuk membangun karakter diri (Kompas, 11 Oktober 2012). Demikian pernyataan dari wakil menteri tersebut menyiratkan bahwa kurikulum 2013 ini memberikan kesempatan dan fasilitas memadai untuk menghasilkan insan yang cerdas intelektual dan nuraninya.

Pada awal diwacanakan kurikulum 2013, sosialisasi dan uji publik dilaksanakan dibeberapa sekolah. Uji publik dilakukan melalui berbagai media dan forum pertemuan. Selain itu, untuk penerapan kurikulum 2013 juga dilakukan dengan berbagai saran dan pertimbangan. Dengan berbagai saran, masukan dan kritikan yang disampaikan kepada Kemdikbud, maka target untuk menerapkan kurikulum 2013 meliputi 6.325 sekolah untuk seluruh jenjang (SD 2.598, SMP 1.436, SMA 1.1270 dan SMK 1.021) (Suyanto, Kompas 8 Juli 2013). Target yang tidak terlalu masif ini memang dinilai realistis untuk sebuah kebijakan baru dalam bidang pendidikan. Hal ini dikarenakan persiapan yang dilakukan tidak mudah dan harus berkelanjutan. Tentu saja peran dari LPTK sangat besar terhadap kesuksesan penerapan kurikulum 2013. LPTK mempersiapkan calon pendidik yang matang dan kompeten untuk terjun dalam pelaksanaan pembelajaran di sekololah.

Perguruan Tinggi seperti UNY memiliki program untuk mempersiapkan kompetensi mendidik untuk para lulusan Sarjana 
Pendidikan. Program integral dalam perkuliahan yaitu Pembelajaran Mikro (Micro Teaching) sebagai tahapan awal untuk melaksanakan program PPL (Praktek Pengajaran Lapangan) di sekolah-sekolah yang dipilih. Pelaksanaan Pembelajaran Mikro tentu tidak terlepas dari sistem dan kebijakan yang sedang diberlakukan oleh pemerintah dalam bidang pendidikan disetiap jenjang. Mahasiswa selayaknya memahami kebijakan yang sedang diberlakukan dan melatih ketrampilan sehingga mampu melaksanakan pembelajaran yang senyatanya di sekolah. Mahasiswa lulusan LPTK diharapkan menjadi motor penggerak kesuksesan kurikulum 2013 yang membawa misi untuk memajukan kualitas pendidikan di Indonesia.

Oleh karena itu, perlu dilakukan sebuah penelitian terkait dengan pemahaman mahasiswa dari LPTK tentang kurikulum 2013. Penelitian ini mampu dijadikan sebagai bahan evaluasi terkait dengan sistem pengajaran di LPTK akibat sistem pendidikan yang mengalami perubahan karena kebijakan kurikulum baru. Tentu saja, diharapkan mahasiswa siap untuk diterjunkan di lapangan dengan mampu tampil dan mempraktekan secara baik pengajaran di kelas sesuai dengan kurikulum yang berlaku.

Pengajaran mikro atau yang dikenal dengan Microteaching merupakan suatu program yang masuk dalam kurikulum di jurusan kependidikan. Program ini dipersiapkan secara khusus untuk mahasiswa yang notabene adalah calon pendidik dan akan mendapatkan gelar Sarjana Pendidikan agar memiliki ketrampilan mengajar. Pengajaran mikro mempersiapkan mahasiswa untuk terjun di lapangan dengan mengajar secara langsung kepada siswa dalam PPL (Praktik Pengajaran Lapangan) di sekolah-sekolah yang ditunjuk oleh kampus. 
Saliman, Supardi, Raras Gistha Rosardi

Direktorat Pembinaan Pendidik dan Tenaga Kependidikan dan Direktorat Ketenagaan DIKTI Depdiknas (2004) telah merumuskan dan mengembangkan Standar Kompetensi Guru Pemula (SKGP) SMP dan SMA yang mencakup empat standar kompetensi, yaitu: (1) penguasaan bidang studi, (2) pemahaman tentang peserta didik, (3) penguasaan pembelajaran yang mendidik, (4) pengembangan kepribadian dan keprofesionalan. Oleh karena itu calon guru dan guru seharusnya mendapatkan bekal yang memadai agar menguasai kompetensi yang diharapkan. Untuk mewujudkan kompetensi tersebut, maka dapat melalui preservice maupun inservice training. Salah satu bentuk preservice training bagi calon guru tersebut adalah melalui pembentukan kemampuan dasar mengajar (teaching skill) baik teoritis maupun praktis. Secara praktis, bekal kemampuan mengajar dapat dilatihkan melalui kegiatan microteaching atau pengajaran mikro.

Pengajaran mikro merupakan pelatihan tahap awal dalam pembentukan kompetensi mengajar melalui pengaktualisasikan kompetensi dasar mengajar. Menurut Tim Panduan Pengajaran Mikro UPPL UNY (2009: 1-2), pengajaran mikro merupakan suatu metode pembelajaran atas dasar kinerja yang tekniknya dilakukan dengan melatihkan komponen-komponen kompetensi dasar mengajar dalam proses pembelajaran sehingga calon guru benarbenar mampu menguasai setiap komponen satu persatu atau beberapa komponen secara terpadu dalam situasi pembelajaran yang disederhanakan.

Pengajaran mikro mencakup kegiatan orientasi observasi pembelajaran di sekolah dan praktik mengajar dengan model peer teaching. Dalam pengajaran mikro, mahasiswa dapat dilatih untuk kompetensi dasar mengajar, dengan kompetensi materi, peserta 
didik, maupun waktu presentasi yang dibatasi. Pengajaran mikro juga sebagai sarana latihan untuk tampil berani menghadapi kelas, mengendalikan emosi, ritme pembicaraan.

Pemerintah terus berupaya untuk mewujudkan sistem pendidikan yang lebih baik, salah satunya dengan melakukan perbaikan dan perubahan kurikulum. Zaman semakin berkembang dan dinamika kehidupan semakin kompleks sehingga memang dirasa perlu untuk terus melakukan inovasi. Dalam dunia pendidikan, inovasi terus dibutuhkan tidak hanya dari internal akan tetapi dari eksternal. Dari faktor internal kualitas guru perlu ditingkatkan secara terus menerus, perlu perbaikan dari segi seleksi dan sistematika kerja. Seperti yang dikemukakan oleh Gede Raka (2011: 70-73) bahwa salah satu jalan untuk mengefektifkan pendidikan karakter di sekolah adalah dengan pengembangan kapabilitas guru melalui: 1) Memantapkan kualifikasi sebagai pendidik, 2) Belajar secara berkesinambungan dan 3) Pengembangan kreativitas

Untuk faktor eksternal salah satunya dengan kebijakan yang disiapkan oleh pemerintah. Pada tahun 2013 ini pendidikan di Indonesia akan hadir dengan nuansa baru yaitu kurikulum 2013 yang sudah disosialisasikan oleh Menteri Pendidikan dan Kebudayaan Republik Indonesia Prof. Dr. Ir Mohammad Nuh. Landasan pengembangan kurikulum 2013 seperti yang tertulis dalam bahan uji publik kurikulum 2013 Kemendikbud (2012: 6) yaitu:

a. Aspek filosofis

1) Filosofi pendidikan berbasis pada nilai-nilai luhur, nilai akademik, kebutuhan peserta didik, dan masyarakat.

2) Kurikulum berorientasi pada pengembangan kompetensi.

b. Aspek yuridis

1) RPJMN 2010-2014 Sektor Pendidikan, terdiri dari perubahan metodologi pembelajaran dan penataan kurikulum 
Saliman, Supardi, Raras Gistha Rosardi

2) INPRES Nomor 1 Tahun 2010

Percepatan pelaksanaan prioritas pembangunan nasional: penyempurnaan kurikulum dan metode pembelajaran aktif berdasarkan nilai-nilai budaya bangsa untuk membentuk daya saing dan karakter bangsa.

c. Aspek Konseptual

1) Relevansi

2) Model kurikulum berbasis kompetensi

3) Kurikulum lebih dari sekedar dokumen

4) Proses pembelajaran: aktivitas belajar, output belajar, outcome belajar

5) Penilaian: Kesesuaian teknik penilaian dengan kompetensi, penjenjangan penilaian

Dalam kebijakan yang disosialisasikan sejak tahun 2010 terkait dengan pembangunan karakter bangsa, pemerintah berupaya untuk melakukan tindakan konkret sehingga tidak hanya berupa wacana. Kurikulum 2013 merupakan salah satu upaya pemerintah untuk mewujudkan kebijakan tersebut. Dalam kurikulum baru ini, pemerintah berupaya memasukkan nilai-nilai karakter sehingga pendidikan tidak hanya mencerdaskan peserta didik secara kognitif. Berikut ini adalah standar kompetensi lulusan yang dirancang oleh pemerintah untuk kurikulum 2013.

Tabel 1.

Standar Kompetensi Lulusan

\begin{tabular}{|l|l|l|c|c|}
\hline Domain & Elemen & \multicolumn{1}{|c|}{ SD } & \multicolumn{1}{c|}{ SMP } & \multicolumn{1}{|c|}{ SMA/SMK } \\
\hline Sikap & Proses & $\begin{array}{l}\text { Menerima+menjalankan+menghargai+menghayati+ } \\
\text { mengamalkan }\end{array}$ \\
\hline & Individu & $\begin{array}{l}\text { Beriman, berakhlak mulia jujur, disiplin, tanggung } \\
\text { jawab, peduli, santun) rasa ingin tahu, estetika, } \\
\text { percaya diri, motivasi internal }\end{array}$ \\
\hline & Sosial & $\begin{array}{l}\text { Toleransi, gotong royong, musyawarah, dan } \\
\text { kerjasama }\end{array}$ \\
\hline $\begin{array}{l}\text { Ketrampil } \\
\text { an }\end{array}$ & Plam & $\begin{array}{l}\text { Pola hidup sehat, ramah lingkungan, patriotik, dan } \\
\text { cinta perdamaian }\end{array}$ \\
\hline & Abstrak & $\begin{array}{l}\text { Mengamati+Menanya+Mencoba+Mengolah+Menyaji+ } \\
\text { Menalar+Mencipta }\end{array}$ \\
\hline
\end{tabular}




\begin{tabular}{|l|l|l|}
\hline & Konkret & $\begin{array}{l}\text { Menggunakan, Mengurai, Merangkai, Memodifikasi, } \\
\text { Membuat, Mencipta }\end{array}$ \\
\hline $\begin{array}{l}\text { Pengetah } \\
\text { uan }\end{array}$ & Proses & $\begin{array}{l}\text { Mengetahui+Memahami+Menerapkan+Menganalisa+ } \\
\text { Mengevaluasi }\end{array}$ \\
\hline & Objek & Ilmu Pengetahuan, Teknologi, Seni, dan Budaya \\
\hline & Subjek & Manusia, Bangsa, Negara, Tanah air dan dunia \\
\hline
\end{tabular}

Sumber: Kemendikbud, 2012: 30

Berdasarkan tabel standar kompetensi lulusan yang disajikan tersebut dapat kita pahami bahwa internalisasi karakter akan terwujudkan dalam pembelajaran yang diterima oleh peserta didik. Dengan domain yang tidak hanya mengacu pada aspek pengetahuan, akan tetapi sikap dan ketrampilan. Pada domain sikap, baik dari jenjang SD, SMP dan SMA diberikan penguatan nilai-nilai karakter baik dari elemen proses, individu, alam dan sosial.

Pada elemen proses akan diwujudkan pada saat pembelajaran kelas berlangsung dan terjadi interaksi antara pendidik dan peserta didik. Pendidikan tidak hanya berproses pada penerimaan saja akan tetapi ada proses yang lain, seperti penghargaan, penghayatan, pengamalan. Untuk elemen individu, dibutuhkan instrumen untuk mengukur terkait dengan sikap tiap peserta didik. Pendidik harus bekerja sama dengan semua warga sekolah untuk dapat membangun karakter tiap peserta didik dengan memperhatikan dan ikut mengevaluasi kondisi lingkungan belajar peserta didik. Setiap diri peserta didik bertanggung jawab terhadap dirinya sendiri, itu yang menjadi kunci pokok dalam penilaian untuk domain sikap. Dengan prinsip seperti ini, maka setiap individu terbentuk menjadi pribadi yang mandiri.

Pada elemen sosial dan alam, pada domain sikap ini peserta didik tidak hanya diberikan kompetensi untuk mengetahui tentang suatu pengetahuan akan tetapi mulai dengan kenapa suatu 
Saliman, Supardi, Raras Gistha Rosardi

pengetahuan. Misalnya dalam sosial, peserta didik diberikan kompetensi tentang mata pencaharian penduduk. Peserta tidak hanya paham akan jenis-jenis mata pencaharian penduduk, apa saja yang dilakukan, dan bagaimana proses pekerjaannya. Akan tetapi peserta didik diarahkan kepada kenapa ada mata pencaharian penduduk, untuk apa dan bagaimana harus mengelola suatu mata pencaharian agar menjadi berkah dan bermanfaat luas. Hal ini akan menjadikan peserta didik memiliki rasa peduli, baik itu terhadap diri sendiri, orang lain, masyarakat dan terutama pada Tuhannya.

Dalam upaya penanaman terhadap mahasiswa tentang kurikulum 2013, Jurusan Pendidikan IPS FIS, UNY merancang dalam kurikulum jurusan dan terinternalisasi dalam beberapa mata kuliah. Mata kuliah yang dirancang untuk upaya pemahaman kurikulum 2013 antara lain: Strategi Pembelajaran IPS, Perencanaan Pembelajaran IPS dan Penilaian Hasil Belajar IPS. Mata kuliah yang dirancang untuk memberikan pemahaman kepada mahasiswa adalah mata kuliah yang berkaitan langsung dengan kondisi di sekolah.

Upaya pemerintah untuk memperbaiki kualitas pendidikan di Indonesia melalui perubahan kurikulum 2013 mengakibatkan ada beberapa bagian atau elemen yang mengalami perubahan. Berdasarakan Bahan Uji Publik Kurikulum 2013 Kemendikbud (2012: 23-36), elemen perubahan tersebut meliputi: kompetensi lulusan, kedudukan mata pelajaran, pendekatan (isi), struktur kurikulum. Kompetensi Lulusan yaitu pada semua jenjang pendidikan, diharapkan adanya peningkatan dan keseimbangan softskill dan hardskills yang meliputi aspek kompetensi sikap, 
ketrampilan dan pengetahuan. Kedudukan mata pelajaran yaitu mata pelajaran dikembangkan dari kompetensi

1) Pendekatan (Isi)

Pada tingkat SD dengan pendekatan tematik terintegratif pada semua mata pelajaran, sedangkan untuk SMP dengan pendekatan mata pelajaran, SMA dan SMK dengan pendekatan mata pelajaran wajib dan pilian sedangkan SMK ditambah dengan vokasi.

2) Struktur kurikulum

Pada struktur kurikulum 2013 terdiri dari:

a) SD : Mata pelajaran SD holistik dan integratif dan fokus pada alam, sosial dan budaya.

b) SMP: TIK menjadi media bagi semua mata pelajaran dan pengembangan diri terintegrasi pada mata pelajaran dan ekstrakurikuler.

c) SMA : Terdapat mata pelajaran wajib dan mata pelajaran pilihan. Pemilihan mata pelajaran disesuaikan dengan bakat dan minat.

d) SMK : penyesuian jenis keahlian didasarkan pada spektrum kebutuhan saat ini, adanya tren perubahan berdasarkan pada perkembangan industri.

3) Proses pembelajaran

a) Standar proses yang semula terfokus pada eksplorasi, elaborasi dan konfirmasi dilengkapi dengan mengamati, menanya, mengolah, menalar, menyajikan, menyimpulkan dan mencipta.

b) Belajar tidak hanya terjadi di ruang kelas, tetapi juga di lingkungan sekolah dan masyarakat

c) Guru bukan satu-satunya sumber belajar 
Saliman, Supardi, Raras Gistha Rosardi

d) Sikap tidak diajarkan secara verbal akan tetapi melalui contoh dan keteladanan

4) Penilaian

a) Penilaian berdasarkan kompetensi

b) Penilaian tidak hanya dilakukan dengan tes akan tetapi dengan penilaian otentik (mengukur semua kompetensi sikap, pengetahuan dan ketrampilan berdasarkan proses dan hasil)

c) Penilaian tidak hanya pada level Kompetensi Dasar akan tetapi pada kompetensi inti dan SKL

d) Pemanfaatan portofolio yang dibuat oleh siswa menjadi instrumen yang utama.

5) Ekstrakurikuler

Pada semua jenjang pendidikan, pramuka menjadi ekstrakurikuler yang wajib bagi siswa.

Deskripsi mata kuliah strategi pembelajaran IPS adalah memberikan bagaimana strategi pembelajaran IPS, metode pembelajaran dan sumber-sumber yang dapat digunakan dalam pembelajaran IPS, serta kemungkinan pengembangannya. Dalam hal ini, strategi pembelajaran yang disarankan untuk penerapan kurikulum 2013 diberikan melalui mata kuliah ini. Penilaian hasil belajar IPS yaitu mengembangkan kemampuan mahasiswa dalam memberikan evaluasi proses belajar yang telah berlangsung. Mata kuliah ini berisi tentang pengertian evaluasi, pengukuran dan macam-macam tes maupun nontes yang dapat digunakan dalam mengevaluasi. Penilaian merupakan salah satu elemen perubahan yang ada dalam kurikulum 2013, sehinga pemahaman penilaian berdasarkan kurikulum 2013 dapat diberikan melalui mata kuliah ini.

Selain mata kuliah strategi pembelajaran IPS dan penilaian hasil belajar IPS, mata kuliah perencanaan pembelajaran IPS juga 
dirancang untuk mampu memanamkan kurikulum 2013 kepada mahasiswa. Mata kuliah perancanaan pembelajaran IPS adalah mengetahui teknik perencanaan pengajaran dan jenis-jenis rencana pengajaran. Isi mata kuliah penjabaran tujuan pengajaran, pemilihan media pengajaran, penilaian kinerja siswa dan pengelolaan kelas. Untuk mata kuliah perencanaan pembelajaran dapat diberikan pemahaman kurikulum 2013 karena pada mata kuliah ini mahasiswa diberikan ketrampilan untuk membuat perangkat pembelajaran sesuai dengan kurikulum 2013. Misalnya untuk standar proses yang semula terfokus pada eksplorasi, elaborasi dan konfirmasi dilengkapi dengan mengamati, menanya, mengolah, menalar, menyajikan, menyimpulkan dan mencipta. Hal tersebut diberikan pada mata kuliah perencanaan pembelajaran IPS karena salah satu kegiatan mahasiswa dalam mata kuliah ini adalah membuat RPP (Rencana Perencanaan Pembelajaran) kurikulum 2013 sebagai salah satu dari perangkat pembelajaran.

Penelitian ini memiliki tujuan antara lain:

1. Untuk mengetahui sejauh mana tingkat pemahaman mahasiswa peserta pengajaran mikro terhadap kurikulum 2013 di jurusan Pendidikan IPS

2. Untuk mengetahui upaya yang dilakukan selama ini di jurusan Pendidikan IPS agar mahasiswa peserta pengajaran mikro mampu memahami kurikulum 2013

\section{Metode Penelitian}

Penelitian ini merupakan jenis penelitian Kuantitatif. Populasi penelitian adalah mahasiswa Pendidikan IPS semester 6 . Penelitian ini akan dilakukan di jurusan Pendidikan IPS ada mata kuliah Mikro Teaching. Penelitian dilakukan pada bulan April 
Saliman, Supardi, Raras Gistha Rosardi

sampai dengan Nopember 2014. Peneliti mengambi data dari angket, observasi dan wawancara dengan mahasiswa Jurusan Pendidikan IPS semester 6, FIS UNY. Teknik pengumpulan data dalam penelitian sosial yang lazim digunakan menurut Sanaplah Faisal (2001:51) adalah angket (questionaire), wawancara (interview), observasi (observation), dokumenter (secondary sources), dan tes (test). Angket digunakan untuk memperoleh data secara numerik terkait dengan persenteasi pemahaman mahasiswa peserta pengajaran mikro terhadap kurikulum 2013. Observasi digunakan untuk memperoleh data atau informasi tentang praktik yang dilakukan oleh mahasiwa peserta pengajaran mikro terhadap pemahaman kurikulum 2013. Teknik dokumentasi dalam penelitian ini digunakan untuk memperoleh data mengenai pelaksanaan pengajaran mikro dengan menggunakan kurikulum 2013 yang dilakukan oleh mahasiswa. Data dalam penelitian ini disajikan dalam bentuk deskritif kuantatif yaitu persentase pemahaman mahasiswa peserta pengajaran mikro dan pembahasan secara kualitatif dalam bentuk kalimat.

Teknik pemeriksaan keabsahan data menggunakan uji validitas dan teknik trianggulasi data. Uji validitas dalam penelitian ini menggunakan pengujian validitas isi dan konstrak. Validitas isi adalah derajat dimana sebuah tes mengukur cakupan substansi yang ingin diukur. Validitas konstruk adalah derajat yang ingin diukur berdasarkan konstruksi teori dimana instrumen tersebut dibuat. Dalam hal ini instrumen dikonstruksi tentang aspek-aspek yang akan diukur dengan mengacu pada landasan teori dibawah bimbingan ahli. Jumlah tenaga ahli dibidang materi tiga orang ahli. Penentuan validitas rasional berdasarkan expert judgment (pendapat ahli). Teknik triangulasi yang digunakan dalam penelitian ini meliputi triangulasi sumber, dilakukan untuk 
membandingkan hasil pengamatan antara dosen dengan peneliti. Sedangkan triangulasi metode digunakan untuk mengecek ulang informasi hasil pengamatan dan tes akhir tindakan dengan hasil wawancara.

Teknik Analisis Data menggunakan statistik deskriptif digunakan untuk menyajikan data dalam bentuk tabel (distribusi frekuensi, ukuran pemusatan, ukuran letak, ukuran keragaman) gambar diagram maupun grafik sehingga mudah dipahami. Untuk angket atau kuesioner instrumen yang telah diisi dicari skor keseluruhannya, sehinga tiap responden memiliki skor. Selanjutnya dicari skor keseluruhan responden dalam satu kelas dan simpangan bakunya. Teknik analisis data dalam penelitian ini adalah deskriptif yaitu teknik analisis data dengan menggunakan paparan sederhana dari data yang diperoleh kemudian dilakukan analisis secara mendalam.

Teknik analisis yang digunakan dalam penelitian ini adalah analisis interaktif. Dalam model analisis ini, tiga komponen analisisnya yaitu reduksi data, sajian data, dan penarikan kesimpulan atau verivikasi, aktivitasnya dilakukan dalam bentuk interaktif dengan proses pengumpulan data sebagai suatu proses yang berlanjut, berulang, dan terus-menerus hingga membentuk sebuah siklus. Dalam proses ini aktivitas peneliti bergerak di antara komponen analisis dengan pengumpulan data selama proses ini masih berlangsung. Selanjutnya peneliti hanya bergerak diantara tiga komponen analisis tersebut. Reduksi data dapat diartikan sebagai proses pemilihan, pemusatan perhatian pada penyederhanaan, pengabstrakan, dan transformasi data "kasar" yang muncul dari catatan tertulis di lapangan. Dengan demikian reduksi data merupakan suatu bentuk analisis yang menajamkan, menggolongkan, mengarahkan, membuang yang tidak perlu dan 
Saliman, Supardi, Raras Gistha Rosardi

mengorganisasi data dengan cara sedemikian rupa sehingga kesimpulan finalnya dapat ditarik dan diverifikasi. Secara sederhana dapat dijelaskan dengan "reduksi data" dan perlu mengartikannya sebagai kuantifikasi. Data kualitatif dapat disederhanakan dan ditransformasikan dalam aneka macam cara: melalui seleksi yang ketat, melalui ringkasan, menggolongkannya dalam suatu pola yang lebih luas dan sebagainya. Sementara itu penyajian data merupakan alur penting yang kedua dari kegiatan analisis interaktif. Suatu penyajian, merupakan kumpulan informasi tersusun yang memberikan kemungkinan adanya penarikan kesimpulan dan pengambilan tindakan. Dalam pengumpulan data model ini, peneliti selalu membuat reduksi data dan sajian data samapai penyusunan kesimpulan. Artinya data yang didapat di lapangan kemudian peneliti menyusun pemahaman arti segala peristiwa yang disebut reduksi data dan diikuti penyusunan data yang berupa ceritera secara sistematis. Reduksi dan sajian data ini disusun pada saat peneliti mendapatkan unit data yang diperlukan dalam penelitian. Pengumpulan data terakhir peneliti mulai melakukan usaha menarik kesimpulan dengan menarik verifikasi berdasarkan reduksi dan sajian data. Jika permasalahan yang diteliti belum terjawab dan atau belum lengkap, maka peneliti harus melengkapi kekurangan tersebut di lapangan terlebih dahulu.

\section{Hasil Penelitian}

Penelitian ini dilakukan di Jurusan Pendidikan IPS, Fakultas Ilmu Sosial, Universitas Negeri Yogyakarta. Jurusan Pendidikan IPS tergolong jurusan yang baru di FIS, UNY. Jurusan Pendidikan IPS berdiri berdasarkan Surat Keputusan Menteri Pendidikan Nasional RI Nomor 1951/D/T/2007 dan mulai 
menerima mahasiswa jenjang Strata 1 tahun 2008. Hal ini sesuai dengan sistem pendidikan nasional No. 20 Tahun 2003 bahwa guru dari jenjang pendidikan dasar sampai menengah harus memiliki kualifikasi sebagai lulusan Sarjana Pendidikan IPS.

Jurusan Pendidikan IPS memiliki visi yaitu Jurusan Pendidikan IPS Universitas Negeri Yogyakarta dalam kurun waktu 2013-2018 dapat menghasilkan lulusan yang berkarakter, profesional dan memenuhi standar nasional serta memiliki keunggulan kompetitif dalam mengembangkan pembelajaran IPS dengan pendekatan transdisipliner. Adapun misi dari jurusan Pendidikan IPS antara lain: 1) Melaksanakan pendidikan IPS yang berkualitas berlandaskan etika dan moral untuk menghasilkan lulusan yang berkarakter dan profesional, 2) Melaksanakan penelitian yang berguna untuk pendalaman dan pengembangan ilmu-ilmu sosial khususunya di bidang penddikan IPS, 3) Melaksanakan pengabdiam pada masyarakat untuk menumbuhkembangkan kepekaan dan tanggung jawab sosial yang dilandasi oleh bidang keilmuan IPS, 4) Menyelenggarakan proses pembelajaran yang sistematis, terstruktur dan terukur untuk menghasilkan lulusan yang memenuhi standar nasional. Untuk menunjang tercapaiya visi dan misi jurusan Pendidikan IPS, maka dalam kurikulum jurusan terdapat mata kuliah yang wajib ditempuh oleh mahasiswa guna memberikan ketrampilan pedagogik.

Penelitian dilakukan dengan menyebar angket kepada mahasiswa semester 6 yang pada saat itu sedang menempuh mata kuliah PPL (Praktek Pengajaran Lapangan). Penelitian dilakukan pada bulan Juli-Agustus 2014 memberikan hasil sebagai berikut: 
Saliman, Supardi, Raras Gistha Rosardi

Tabel 2.

Persentase Pemahaman Kurikulum 2013

\begin{tabular}{|c|c|c|c|}
\hline Kategori & Tingkat & Jumlah & Persentase \\
\hline Sangat tinggi & $71-96$ & 52 & $43.68 \%$ \\
\hline Tinggi & $49-70$ & 29 & $24.36 \%$ \\
\hline Sedang & $25-48$ & 0 & $0 \%$ \\
\hline Rendah & $<24$ & 0 & $0 \%$ \\
\hline Jumlah & & $\mathbf{8 1}$ & $\mathbf{1 0 0 \%}$ \\
\hline
\end{tabular}

Berdasarkan tabel diatas, maka dapat ditampilkan dengan grafik sebagai berikut:

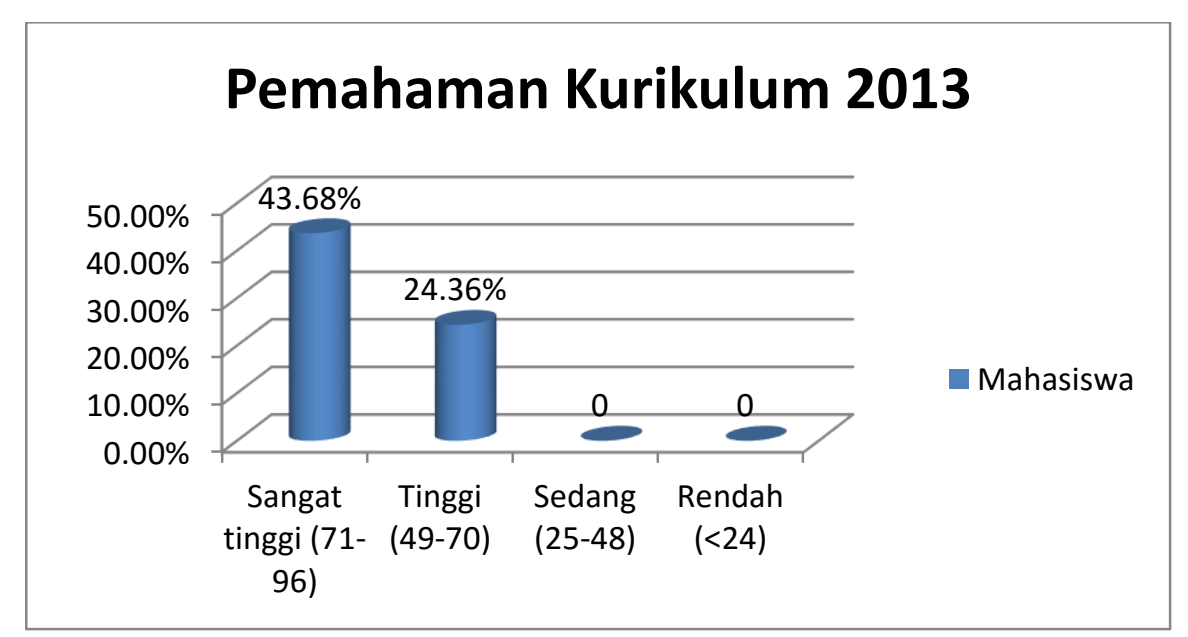

Gambar 1 .

Persentase Pemahaman Kurikulum 2013

Berdasarkan hasil penelitian tersebut diperoleh data bahwa mahasiswa yang memiliki tingkat pemahaman sangat tinggi sebesar 43,68\%, tinggi sebesar 24,36\%, sedang sebesar 0\% dan rendah sebesar 0\%. Kategori pemahaman sangat tinggi diperoleh sebanyak 43,68\% mahasiswa, walaupun belum sampai 50\% akan tetapi persentase ini dapat dikatakan sudah baik karena pada tahun 2014 mahasiswa peserta pengajaran mikro dan PPL. Mata kuliah yang menunjang ketrampilan pedagogik antara lain: Strategi Pembelajaran IPS, Perencanaan Pembelajaran IPS, Microteaching, Penilaian Pembelajaran IPS, Media Pembelajaran IPS dan Praktek Pengajaran Lapangan (PPL). 
Berdasarkan data hasil penelitian tersebut dapat diketahui bahwa pemahaman mahasiswa jurusan Pendidikan IPS terhadap kurikulum 2013 sangat didukung oleh mata kuliah yang mendukung terhadap kebijakan pendidikan, perangkat pembelajaran di sekolah, dan strategi pembelajaran di kelas. Pemahaman kurikulum 2013 diperlukan agar mahasiswa jurusan Pendidikan IPS siap untuk terjun di lapangan dalam kegiatan PPL (Praktek Pengajaran Lapangan). Hal ini dikarenakan pada mahasiswa yang dijadikan sampel pada penelitian ini merupakan angkatan pertama yang ikut terlibat dalam penerapan kurikulum 2013.

Jurusan Pendidikan IPS sangat mempersiapkan mahasiswa untuk mampu memahami dan menerapkan kurikulum 2013 di kelas terutama pada mata pelajaran IPS di SMP yang notabene banyak mengalami perubahan pada materi dan penyajian dalam kelas. Pada penelitian ini, pemahaman kurikulum 2013 dapat terlihat dari beberapa indikator antara lain pendekatan (isi), struktur kurikulum, proses pembelajaran, penilaian. Elemenelemen tersebut disiapkan oleh jurusan Pendidikan IPS mulai dari semester 3 sampai pada semester 6 untuk bekal mahasiswa di sekolah ketika pelaksanaan PPL. Karena kurikulm 2013 merupakan produk kebijakan baru dari pemerintah, maka UNY dan jurusan Pendidikan IPS selaku lembaga akademisi mempersiapkan diri untuk memberikan kompetensi kepada mahasiswa terkait kurikulum 2013.

Hasil penelitian ini menunjukkan bahwa mahasiswa memperoleh bekal cukup baik untuk menerapkan kurikulum 2013 pada saat PPL di Sekolah. Dosen-dosen di jurusan Pendidikan IPS sudah mempersiapkan materi perkuliahan yang mampu mengasah kompetensi mahasiswa untuk mampu beradaptasi dengan 
Saliman, Supardi, Raras Gistha Rosardi

kebijakan kurikulum baru dari pemerintah pusat. Selain itu, mahasiswa juga dilibatkan dalam beberapa kegiatan penelitian dan pengabdian masyarakat yang berkaitan dengan kurikulum 2013, sehingga secara tidak langsung pihak jurusan membekali mahasiswa untuk memiliki pemahaman konsep dan kecakapan dalam mempraktikkan kurikulum baru 2013.

Mahasiswa jurusan Pendidikan IPS tanggap terhadap perubahan kurikulum yang diberlakukan di Indonesia. Hal ini terbukti dari sebelum melakukan kegiatan PPL dan sesudah melakukan kegiatan PPL, mahasiswa aktif melakukan diskusi terkait dengan kurikulum 2013 kepada beberapa dosen di jurusan Pendidikan IPS. Dosen-dosen jurusan Pendidikan IPS terlibat dalam kegiatan sosialisasi kurikulum 2013 dan penyusunan perangkat pembelajarannya seperti: buku pegangan guru dan siswa. Dosen-dosen jurusan Pendidikan IPS berpengalaman sebagai instruktur nasional dan penulis buku yang berkaitan dengan kurikulum 2013. Hal ini menjadikan mahasiswa Pendidikan IPS mendapat kesempatan membekali diri dengan para ahli tentang kurikulum 2013.

\section{Simpulan}

1. Tingkat pemahaman mahasiswa peserta pengajaran mikro di jurusan Pendidikan IPS terhadap kurikulum 2013 sudah baik, karena separuh lebih sampel berada pada kategori sangat tinggi tingkat pemahamannya.

2. Upaya yang dilakukan jurusan Pendidikan IPS sudah maksimal. Hal ini dapat diketahui dari pemberian materi terkait dengan kurikulum 2013 dilakukan sejak semester awal yaitu semester 3. Kurikulum jurusan Pendidikan IPS dirancang sedemikian rupa untuk memberikan kompetensi kepada 
JIPSINDO No. 1, Volume 4, Maret 2017

mahasiswanya untuk cakap dalam praktek pengajaran di sekolah dan tanggap terhadap kebijakan terkait dengan perangkat pendidikan.

\section{Daftar Pustaka}

Gede Raka, dkk. (2011). Pendidikan karakter di sekolah. Jakarta: Kompas Gramedia.

Kementerian Pendidikan dan Kebudayaan. (2012). Bahan uji publik kurikulum 2013. Jakarta: Kemendikbud

\begin{tabular}{l} 
Kemndikbud \\
Pengembangan Kurikulum 2013. Jakarta: \\
\hline Kemdikbud
\end{tabular}

Riana Afifah. (11 Januari 2012). Kurikulum Baru Beri Kesempatan Bangun karakter Anak. Kompas.

Suyanto (2013). Katup Pengaman Kurikulum 2013. Kompas, 8 Juli 2013

Tim Penyusun Panduan Pengajaran Mikro. (2009). Panduan Pengajaran Mikro. Yogyakarta: UPPL UNY. 